\title{
ADOLESCENTS' HEALTHY SPORTS BEHAVIOR MODEL BASED ON THE THEORY OF SOCIAL-ECOLOGICAL SYSTEM
}

\author{
MODELO DE COMPORTAMENTO ESPORTIVO SAUDÁVEL DE ADOLESCENTES BASEADO NA TEORIA \\ DOSISTEMA SOCIOECOLÓGICO
}

Original Article

ARTIGO ORIGINAL

Artículo Original

\section{MODELO DE COMPORTAMIENTO DEPORTIVO SALUDABLE DE ADOLESCENTES BASADO EN LA TEORIA DEL SISTEMA SOCIOECOLÓGICO}

\begin{abstract}
Chenxi Yang ${ }^{1}$
(Physical Education Professional) Rui Wang' (D)

(Physical Education Professional)

1. Department of Sports Science and Physical Education, Northeast Agricultural University, Harbin, China.
\end{abstract}

\section{Correspondence:}

Rui Wang

Department of Sports Science and Physical Education, Northeast Agricultural University, Harbin, 150030, China.

yang0321171@163.com

\begin{abstract}
Introduction: Education administrative departments and schools should regard sports as an integral part of school education and allow students to use sports every day. Guarantee the time for sports activities; schools should organize various forms of extracurricular sports activities". Objective: Based on the ecological system theory, the paper constructs a three-factor structural model that restricts youth sports participation and compiles a scale of factors restricting youth sports participation. Methods: The thesis selected 1,800 primary and secondary school students as the research object and used exploratory factor analysis to explore the questionnaire structure on the obstacles to sports participation. Results: 1) Exploratory factor analysis, the cumulative contribution rate of the first three factors extracted was $58.90 \%$, and the load of each factor was more significant than 0.4 . The three factors were school factors, family factors, and personal factors in order; 2) Reselected subjects, Exploring the three-factor structural model of obstacles to sports participation were verified. The final modified model RMSEA was 0.071, CFI was 0.98, and X2/df was 8.55. The three factors were school factors, family factors, and personal factors. Conclusions: The fit of the threefactor structural indicators restricting youth sports participation is ideal, and the model is relatively stable. The "Questionnaire on Restricting Factors of Youth Sports Participation" can be used as a measurement tool to evaluate and understand youth sports participation constraints. Level of evidence Il; Therapeutic studies - investigation of treatment results.
\end{abstract}

Keywords: Adolescent; Sports; Healthy behaviors; Restrictive factors; Exercise.

\section{RESUMO}

Introdução: Departamentos administrativos de educação e escolas devem considerar os esportes como parte integrante da educação escolar e permitir que os alunos pratiquem esportes todos os dias. Garantia de tempo para atividades esportivas; as escolas devem organizar várias formas de atividades esportivas extracurriculares. Objetivo: Com base na teoria do sistema ecológico, o artigo constrói um modelo estrutural de três fatores que restringe a participação em esportes de jovens e compila uma escala de fatores que restringem a participação em esportes de jovens. Métodos: a tese selecionou 1.800 alunos do ensino fundamental e médio como objeto de pesquisa e utilizou uma análise fatorial exploratória para explorar a estrutura do questionário sobre obstáculos à participação esportiva. Resultados: 1) Análise fatorial exploratória, a taxa de contribuição cumulativa dos três primeiros fatores extraídos foi de 58,90\% e a carga de cada fator foi mais significativa do que 0,4. Os três fatores eram fatores escolares, fatores familiares e fatores pessoais em ordem; 2) Foram verificados os temas reelecionados, explorando o modelo estrutural de três fatores de obstáculos à participação esportiva. O modelo RMSEA modificado final foi 0,071, CFI foi 0,98 ex2 / df foi 8,55. Os três fatores eram fatores escolares, fatores familiares e fatores pessoais. Conclusões: $O$ ajuste dos indicadores estruturais de três fatores que restringem a participação dos jovens em esportes é ideal e o modelo é relativamente estável. O "Questionário sobre Fatores Restritivos da Participação em Esportes de Jovens" pode ser usado como uma ferramenta de medição para avaliar e compreender as limitações da participação em esportes de jovens. Nível de evidência Il; Estudos terapêuticos: investigação dos resultados do tratamento.

Descritores: Adolescente; Esportes; Hábitos saudáveis; Fatores limitantes; Exercício físico.

\section{RESUMEN}

Introducción: Los departamentos administrativos de educación y las escuelas deben considerar los deportes como una parte integral de la educación escolar y permitir que los estudiantes utilicen los deportes todos los días. Garantizar el tiempo para actividades deportivas; las escuelas deberían organizar diversas formas de actividades deportivas extracurriculares. Objetivo: Basado en la teoría del sistema ecológico, el artículo construye un modelo estructural de tres factores que restringe la participación deportiva juvenil y compila una escala de factores que restringen la participación deportiva juvenil. Métodos: La tesis seleccionó a 1.800 estudiantes de primaria y secundaria como objeto de investigación y utilizó un análisis factorial exploratorio para explorar la estructura del cuestionario 
sobre los obstáculos a la participación deportiva. Resultados: 1) Análisis factorial exploratorio, la tasa de contribución acumulada de los tres primeros factores extraídos fue de 58,90\% y la carga de cada factor fue más significativa que 0,4. Los tres factores fueron factores escolares, factores familiares y factores personales en orden; 2) Se verificaron sujetos reselegidos, Explorando el modelo estructural de tres factores de obstáculos a la participación deportiva. El modelo final modificado RMSEA fue 0.071, CFI fue 0.98 y x2 / df fue 8.55. Los tres factores fueron factores escolares, factores familiares y factores personales. Conclusiones: El ajuste de los indicadores estructurales de tres factores que restringen la participación deportiva juveniles ideal y el modelo es relativamente estable. El"Cuestionario sobrefactores restrictivos de la participación deportiva juvenil" puede utilizarse como una herramienta de medición para evaluar y comprender las limitaciones de la participación deportiva juvenil. Nivel de evidencia ll; Estudios terapéuticos: investigación de los resultados del tratamiento.

Descriptores: Adolescente; Deportes; Comportamientos saludables; Factores restrictivos; Ejercicio físico.

\section{INTRODUCTION}

This study defines sports participation as the attitude and behavior of students actively participating in sports. By consulting a large number of kinds of literature, it is found that the domestic research on sports participation is mostly the investigation and research on the sports participation of different groups, pointing out the status quo of sports participation of different groups. Other studies have pointed out factors that affect sports participation. ' Therefore, this research first analyzes the factors that hinder youth sports participation, explores the influencing factor models that hinder youth sports participation, further selects samples, and conducts confirmatory factor analysis on the explored models to eliminate obstacles to students. The factors of sports participation provide an absolute basis to promote students' active participation in sports, thereby enhancing students' physical and mental health.

\section{METHOD}

\section{Research objects}

The thesis first selects 1,800 primary and middle school students to complete the questionnaire on youth sports participation obstacles. It uses exploratory factor analysis to explore the structure of the questionnaire on obstacles to sports participation. Later, the thesis reselected primary and middle school students to complete the questionnaire on youth sports participation obstacles and used confirmatory factor analysis to explore the questionnaire structure. ${ }^{2-3}$

\section{Data processing method}

The paper uses SPSS22.0 and Lisrel8.53 statistical analysis software to conduct exploratory factor analysis and confirmatory factor analysis on the collected data. Variable $M_{i j}$ is divided into intra-group part $\left(M_{i j}-\bar{M}_{. j}\right)$ and between-group part $\bar{M}_{. j}$. Find the path coefficient a (from the independent variable $X_{j}$ to the variable $M_{i j}$, that is, execute the following equation:

Layer-1:

$$
M_{i j}=\beta_{0 j}+\varepsilon_{i j}
$$

Layer-2:

$$
\beta_{0 j}=r_{00}+r_{01}^{a} X_{j}+\mu_{0 j}
$$

Among them, the regression coefficient $r_{01}^{a}$ represents the path coefficient from the independent variable $X_{j}$ to the variable $M_{i j}$. $\beta_{0 j}$ and $r_{00}$ represent the intercepts of regression equations (1) and (2). $\varepsilon_{i j}$ and $\mu_{0 j}$ represent the residuals of regression equations (1) and (2).
The multilayer linear model solves the problem of independent random errors by establishing multilayer regression equations and decomposing errors into errors at various levels. When finding the independent control variable $X_{j}$, the path coefficient b from the variable $M_{i j}$ to the dependent variable $Y_{i j}$ is to execute the following equation:

Layer-1:

$$
Y_{i j}=\beta_{0 j}+\beta_{1 j}\left(M_{i j}-\bar{M}_{. j}\right)+\varepsilon_{i j}
$$

Layer-2:

$$
\beta_{0 j}=r_{00}+r_{01}^{c^{\prime}} X_{j}+r_{02} \bar{M}_{. j}+\mu_{0 j}
$$

$$
\beta_{1 j}=r_{10}^{b}
$$

Where $\bar{M}_{. j}$ represents the group mean of the variable $M_{i j}$. The regression coefficient $r_{10}^{b}$ represents the effect $b_{W}$ of the within-group difference $\left(M_{i j}-\bar{M}_{. j}\right)$ of the variable $M_{i j}$, and the regression coefficient $r_{02}$ represents the effect $b_{B}$ of the between-group part $\bar{M}_{. j}$ of the variable $M_{i j} . X_{j}$ is a fixed value, so the independent variable $X_{j}$ can only affect the inter-group part $M_{i j}$ of the variable $M_{i j}$, but not the intra-group difference $\left(M_{i j}-\bar{M}_{. j}\right)$ of the variable $M_{i j}$. Therefore, the effect $a b=0 \times r_{10}^{b}=0$ of the within-group difference part $\left(M_{i j}-\bar{M}_{. j}\right)$ of the variable $M_{i j}$ and the variable's effect $M_{i j}$ is the effect $a b=0 \times r_{01}^{a}=r_{02}$ of the part $\bar{M}_{. j}$ between the groups. ${ }^{4-5}$ If ab is significantly not 0 or the confidence interval for ab does not include 0 , it means that the multilayer effect is significant. Studies have pointed out that if one of the independent variables, variables, and dependent variables is a level 2 variable, the effect must occur between the level 2 groups. Some studies have pointed out that in 1 analysis, only when the actual meaning of the variable is the level 2 variable represented by $\bar{M}_{. j}$ or the relative position represented by $\left(M_{i j}-\bar{M}_{. j}\right)$, that is, the relative position of the student's self-concept in the class), the effect can only be determined to occur in level 2. Level, otherwise it will reduce statistical power.

\section{RESULTS AND ANALYSIS}

\section{Exploratory factor analysis of the obstacles to youth sports participation}

First, the thesis conducts a first-order factor analysis on the 21item data of the "Sports Participation Obstacle Questionnaire" conducted by 1800 elementary and middle school students. The sampling 
appropriateness $\mathrm{KMO}$ index in EFA is 0.96 , which is a good situation. ${ }^{6}$ The Bartlett sphere test is significant. The probability $P<0.01$ is highly significant, indicating that the data is suitable for factor analysis. Table 1 shows the characteristic value of each factor and the percentage explaining the total variation.

After oblique rotation, it is found that there are three factors with eigenvalues greater than 0.9 , which can explain $62.10 \%$ of the total variation. According to the principal component characteristic gravel diagram, the curve begins to flatten after the third factor, starting from the third. After the factors, each factor's percentage increase to the cumulative total variation is small, so the first three factors are extracted. ${ }^{7}$ The cumulative contribution rate of the variance of the first three factors is $62.10 \%$. Carrying out an orthogonal rotation, a load of each factor after rotation is above 0.3 . Factor 1 contains 9 variables, with loads ranging from 0.388 to 0.723 ; factor 2 contains 4 variables, with loads ranging from 0.620 to 0.750 ; factor 3 contains 8 variables, with loads ranging from 0.231 to 0.697 . Further analysis of the three dimensions found that the dimensional structure is relatively clear, and most of the three dimensions of theoretical ideas are grouped. Figure 1 shows the main component feature map of factors.

Among the three factors extracted: the first factor contains nine topics mainly related to personal living habits and hobbies, named "personal factors"; the second factor includes four topics, which are involved the content is mainly related to the family and the economy and is named "family factors"; the third factor includes eight topics, and the content involved is mainly related to the school, so it is named "school factors."

\section{Confirmatory factor analysis of the reasons for the obstacles to youth sports participation}

The confirmatory factor analysis of the three-factor structure model of the hindrance of youth sports participation

The paper reselects a sample of 1600 primary and middle school students. The confirmatory factor analysis further verifies the fit of the three-factor structure of the obstacles to youth sports participation. The results showed that RMSEA was 0.065 , CFI was 0.87 , and $x 2 / d f$ was 11.25. All fitting values are relatively ideal (Table 2), and a load of each item is more significant than 0.4 .

Table 1. The characteristic value of each factor and the percentage is explaining the total variation.

\begin{tabular}{c|c|c|c}
\hline Factor & Eigenvalues & $\begin{array}{c}\text { Explain the percentage } \\
\text { of total variation/\% }\end{array}$ & $\begin{array}{c}\text { Cumulative } \\
\text { percentage/\% }\end{array}$ \\
\hline Personal reason & 3.939 & 23.03 & 23.03 \\
\hline Family Factors & 3.038 & 19.24 & 32.31 \\
\hline School factor & 3.393 & 16.59 & 59.9 \\
\hline
\end{tabular}

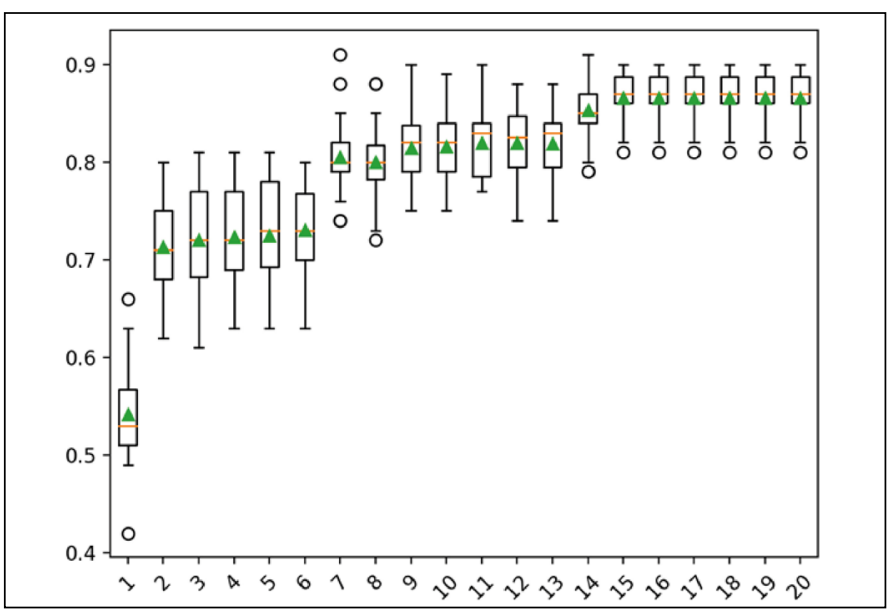

Figure 1. Principal component feature map.
RMSEA is the root mean square of the approximate error. RMSEA less than 0.1 indicates a good fit, and RMSEA less than 0.05 indicates a perfect fit. It is generally believed that RMSEA is below 0.08 . The smaller, the better. CF is a comparative goodness-of-fit index, which refers to the improvement in the theoretical model's degree of fit compared with the independent model of the model established in the research, generally greater than 0.9 , indicating that the theoretical model established by the researcher fits well. ${ }^{8}$ It is generally believed that the larger the CFI above 0.9 , the better, indicating that the fitted model is good. $\times 2 / \mathrm{df}$ is acceptable at $2 \sim 5$, but because $x 2 / d f$ is easily affected by sample size, it is of little significance for evaluating a single model.

A further modified confirmatory factor analysis of the three-factor structure model for the hindrance of youth sports participation

After adjustment, RMSEA is $0.065, \mathrm{CFI}$ is $0.89, \mathrm{X} 2 / \mathrm{df}$ is 7.45 , and the fitting values are all ideal (Table 3 and Figure 2), and a load of each item is more significant than 0.4 .

Table 2. Three-factor structure model of youth sports participation.

\begin{tabular}{c|c|c|c|c|c}
\hline Fitting index & $\mathbf{X}^{2}$ & $\boldsymbol{d f}$ & $\mathbf{X}^{2 / \boldsymbol{d f}}$ & $\mathbf{C F I}$ & RMSEA \\
\hline Value & 1912.02 & 186 & 11.25 & 0.87 & 0.065 \\
\hline
\end{tabular}

Table 3. The first revised three-factor structure model of youth sports participation.

\begin{tabular}{c|c|c|c|c|c}
\hline Fitting index & $\mathbf{X}^{\mathbf{2}}$ & $\boldsymbol{d f}$ & $\mathbf{X} \mathbf{2} \boldsymbol{d f}$ & CFI & RMSEA \\
\hline Value & 1594.14 & 157 & 7.55 & 0.97 & 0.073 \\
\hline
\end{tabular}

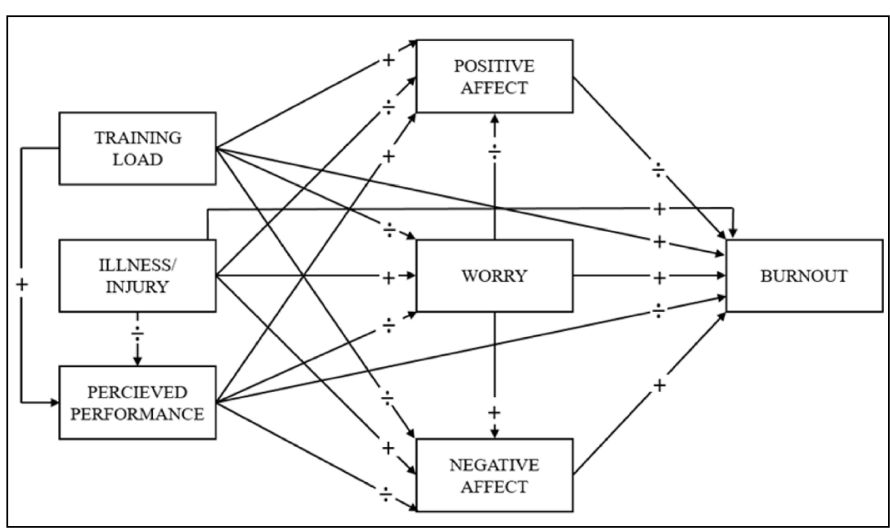

Figure 2. The three-factor structure model of youth sports participation.

\section{DISCUSSION}

This study is based on the integration of previous studies. Since most of the previous studies on the factors of exercise barriers did not pay attention to personal factors, this study added the discussion of these factors. In addition to the external factors of the school and family, the internal factors of the individual also play a vital role in society. In the limited time and space, study and practice; fully excavate from the limited resources for your use; the development of good exercise habits is related to the influence of the school and family, but the most important thing is your efforts. Personal factors mostly refer to one's habits, personal learning attitude, personal enthusiasm, and so on. Better personal habits, positive learning attitudes, and stronger sports motivation will promote youth sports participation. We should strengthen the education of youth sports values. Sports values are fundamental to young people's sports motivation and sports behaviors and determine whether they have sports behaviors and their sports behaviors. Only by strengthening the education of sports values, enhancing the youth's motivation for sports, and cultivating good personal habits and learning attitudes can they promote their sports participation. In addition to personal factors, this study verifies the previous research conclusions, except for the personal influence. ${ }^{9-10}$ 


\section{CONCLUSION}

According to Bronfenbrenner's social-ecological system theory, the factors restricting youth sports participation are personal, family, and school. The questionnaires are compiled through interviews, surveys, and questionnaires for empirical research to establish primary and middle school students'sports participation - the structural model of hindering factors. An exploratory analysis of factors restricting youth sports participation shows that the cumulative contribution rate of the first three factors'variance is $58.90 \%$. The load of each factor after rotation is above 0.40 . The questionnaire is classified into three factors: personal factors, family factors, and school factors. A confirmatory factor analysis of the three-factor structure model that restricts youth sports participation is carried out. After the correction, the RMSEA is 0.071 , and the CFI is 0.98 .
The fitting values are all ideal. Each item's load is more significant than 0.4 , indicating that the youth is restricted. The fit of the three-factor structure of the reasons for sports participation is ideal. Through this model, it is possible to find and solve the problems that hinder youth sports, thereby improving young people's health.

\section{ACKNOWLEDGMENTS}

The work was supported by the Heilongjiang Province higher education teaching reform project "Research on the construction of three self and five guidance teaching system of College Physical Education under the background of" healthy Longjiang "(sjgy20200060)

All authors declare no potential conflict of interest related to this article

AUTHORS' CONTRIBUTIONS: Each author made significant individual contributions to this manuscript. Chenxi Yang analyzed and interpreted the patient data regarding the hematological disease and the transplant. Rui Wang performed the histological examination of the kidney, and was a major contributor in writing the manuscript. All authors read and approved the final manuscript.

\section{REFERENCES}

1. Hamby S, Taylor E, Smith A, Mitchell K, Jones L, Newlin C. New measures to assess the social ecology of youth: A mixed-methods study. Journal of Community Psychology. 2019;47(7): 1666-81.

2. Ince ML. Supporting learning of practitioners and early career scholars in physical education and sports pedagogy. Sport Educ Soc. 2019;24(6):584-96.

3. Santos AJ, Carvalho HM, Gonçalves CE. Personal and ecological factors in school sport: a multilevel approach. South African Journal for Research in Sport, Physical Education and Recreation. 2018;40(1):125-40.

4. Khawaja NG, Allan E, Schweitzer RD. The role of school connectedness and social support in the acculturation in culturally and linguistically diverse youth in Australia. Australian Psychologist. 2018;53(4): 355-64.

5. Register-Mihalik JK, Williams RM, Marshall SW, Linnan LA, MihalikJP, Guskiewicz KM, et al. Demographic parental, and personal factors and youth athletes' concussion-related knowledge and beliefs. Journal of Athletic Training. 2018;53(8):768-75.
6. Jordanoska A. The social ecology of white-collar crime: Applying situational action theory to white-collar offending. Deviant Behavior. 2018;39(11):1427-49.

7. Yassin N, Afifi R, Singh N, Saad R, Ghandour L. "There is zero regulation on the selling of alcohol": the voice of the youth on the context and determinants of alcohol drinking in Lebanon. Qualitative Health Research. 2018;28(5):733-44.

8. Keating XD, Stephenson R, Liu X, Colburn J. Cross-Cultural Comparison of Youth Fitness Testing in China and the US: An Ecological Systems Model Approach. ICHPER-SD Journal of Research. 2019;10(2): 20-7.

9. Horton P. The bullied boy: masculinity, embodiment, and the gendered social-ecology of Vietnamese school bullying. Gender and Education. 2019;31(3): 394-407.

10. Nizamutdinova SM, Larionova IA, Erofeeva MA, Sokolovskaya IE, Gegel LA, Larionova SO, et al. The role of the system of values in harmonizing the personal ecology of young people prone to suicidal behavior. EurAsian J BioSci. 2019;13(2):1719-25. 